\title{
Efficacy of UC-II® Undenatured Type II Collagen on Knee Joint Function in Healthy Subjects: an Exploratory Post Hoc Analysis of a Randomized, Double-blind, Placebo-controlled Trial
}

\section{Zainulabedin Saiyed}

Lonza Inc

Shane Durkee

Lonza Inc

James Bowman

Lonza Inc

Vijaya Juturu ( $\nabla$ vijaya.juturu@lonza.com )

Lonza Inc https://orcid.org/0000-0002-8598-9027

Short report

Keywords: knee pain, undenatured type II collagen, physical function, joint mobility, knee joint function

Posted Date: November 29th, 2021

DOI: https://doi.org/10.21203/rs.3.rs-1083369/v1

License: (c) (i) This work is licensed under a Creative Commons Attribution 4.0 International License.

Read Full License

Version of Record: A version of this preprint was published at The FASEB Journal on May 1st, 2021. See the published version at https://doi.org/10.1096/fasebj.2021.35.S1.03942. 


\section{Abstract}

\section{Background}

UC-II ${ }^{\circledR}$ is a unique joint health ingredient derived from chicken sternum. In a previous study, UC-II ${ }^{\circledR}$ improved knee extension range of motion and extend exercise time before the onset of knee pain in healthy participants.

\section{Methods}

The current exploratory post hoc analyses sought to assess items from the Knee Injury and Osteoarthritis Outcome Score (KOOS) in healthy participants aged $\geq 50$ years who previously participated in a randomized controlled trial. All participants reported knee pain following a standardized stepmill test and were randomized to receive placebo or $40 \mathrm{mg} \mathrm{UC}-I^{\circledR}$ supplementation containing $\geq 3 \%(\geq 1.2 \mathrm{mg})$ undenatured type II collagen for 120 days. For the current post hoc analyses, 17 participants $(U C-I)^{\circledR}=9$, placebo $=8$ ) met the acceptance criteria (age $\geq 50$ years). Analysis was carried out for the KOOS survey results with modified intent-to-treat analysis ( $\mathrm{mITT}$ ). P-values $\leq 0.05$ were considered statistically significant.

\section{Results}

After 120 days of supplementation, participants in the UC-II ${ }^{\circledR}$ supplementation group exhibited statistically significant improvements versus the placebo in select KOOS items including reduced pain during standing upright and going up or down stairs, decreased discomfort in climbing ascending stairs or bending to floor to pick an object, or squatting during physical activity $(p<0.05)$.

\section{Conclusion}

UC-II ${ }^{\circledR}$ supplementation has the potential to improve knee joint function, mobility, flexibility, free movements and performance of daily activities in healthy participants $\geq 50$ years old with exerciseinduced knee pain.

\section{Introduction}

Physical exercise elicits many benefits when performed in a consistent and progressive manner. Indeed, research has shown exercise to improve multiple factors of health, including joint health and function [1], blood pressure [2], glucose disposal [3], body composition [4], and even cognitive function [5]. However, barriers to exercise are plentiful and multifactorial. One such barrier is knee pain; adults with knee pain report lower levels of physical activity and possess uncertainty about their ability to exercise with knee pain [6].

Multiple potential remedies exist to reduce knee pain during exercise, including both activity therapies [1, 7] as well as nutraceutical therapies [8]. One such nutraceutical therapy that has shown promise is 
supplementation with UC-II, a unique undenatured type II collagen supplement derived from chicken sternum. Previous research has shown undenatured type II collagen supplementation to improve knee extension range of motion in healthy individuals with exercise-induced knee pain [9]. Similar benefits have been reported in animal studies, with both arthritic dogs [10] and arthritic horses [11] showing reduced pain during joint manipulation following supplementation periods with undenatured type II collagen.

UC-IIß collagen type II is a naturally occurring ingredient that contains a glycosylated, undenatured type II collagen [12]. Type II collagen is the primary constituent of articular cartilage, which protects against wear and tear associated with joint mobilization and movement. The collagen fiber network fuses with a hydrated proteoglycan matrix to provide protection and cushioning in the joint [13]. Maintaining the integrity of collagen type II fiber matrix is of significant interest to fitness enthusiasts as a loss of cartilage homeostasis can disrupt the collagen-proteoglycan matrix, thus exacerbating knee pain and potentially leading to osteoarthritis [14].

Since knee pain, and joint pain in general, can present as self-diagnosed contraindications to exercise, managing and reducing joint pain is a common step for improving exercise adherence in multiple populations. Previous work by Lugo et al. [9] has shown that consuming $40 \mathrm{mg} /$ day of UC-II® collagen type II (providing $\geq 3 \%$ undenatured type II collagen) for 120-days improved knee range of motion and reduced pain during exercise in healthy participants aged $46.1 \pm 1.5$ years. In addition to assessing multiple indices of knee function and pain during exercise, Lugo and colleagues [9] administered the Knee Injury and Osteoarthritis Outcome Score (KOOS) questionnaire to study participants. The KOOS survey is a validated assessment for individual responses to questions encompassing five domains: (1) pain, (2) other symptoms, (3) function in daily living, (4) function in sport and recreation, and (5) knee-related quality of life. The KOOS survey is useful for assessing changes in knee pathology over time, with or without treatment.

Previously, no significant differences in KOOS survey outcomes between UC-II® supplementation and placebo study groups consisting of healthy participants aged 30 to 65 years with reported knee pain [9]. However, it is known that older individuals typically report greater incidence of knee pain than younger individuals, even in the $>55$ age group [15]. Therefore, in this study, a sub-analysis was undertaken to determine whether or not participants $\geq 50$ years old garnered further benefit from UC-II supplementation over placebo as measured by KOOS survey scores. It was hypothesized that individuals $\geq 50$ years old would experience additional benefits of UC-II supplementation which would be shown in KOOS survey scores relative to a placebo.

\section{Methods}

\section{Study Overview}


This article presents an exploratory post hoc analysis of a previously published randomized, double-blind, placebo-controlled study investigating UC-IIß's effect on improving knee joint function [9]. In this prior study (Figure 1), 55 of 106 screened participants met the eligibility criteria [15]. Only healthy adults who presented with no knee joint pain at rest and no diagnosable markers indicative of active arthritic disease, as outlined by the American College of Rheumatology (ACR) guidelines [16], were admitted into the study [15]. Herein, an analysis was conducted on data collected from the KOOS knee survey at baseline (Day 0) and final post-test (Day 120) in only the participants who were greater than or equal to 50 years of age. The KOOS survey is a validated instrument consisting of 42 questions [17]. KOOS measures subjective information on their knees and their ability to perform daily activities during the past week. Applying this age criteria ( $\geq 50$ years old) to the 55 previously eligible participants yielded 17 total participants, 9 for UC-II and 8 for placebo. Demographic and descriptive data are provided in Table 1 below. The investigational study product, UC-II ${ }^{\circledR}$, is derived from chicken sternum. It is manufactured using a patented, low temperature process to preserve its native structure. For the clinical study, $40 \mathrm{mg}$ of UC-II® material providing $\geq 3 \%$ ( $\geq 1.2 \mathrm{mg}$ ) of undenatured type II collagen, was encapsulated in an opaque capsule with excipients and visually identical placebo capsule was administered [15]. The study protocol was approved by an external institutional review board (IRB) and the study agreed with the Declaration of Helsinki (version 1996). Prior to engaging in study protocols, each participant voluntarily signed an informed consent form approved by the IRB. 
Table 1

Subject Demographics and Descriptive Characteristics.

\begin{tabular}{|c|c|c|}
\hline Variable & $U C-1{ }^{\circledR}(n=9)$ & Placebo $(n=8)$ \\
\hline Age (yr.) & $53.8 \pm 3.4$ & $58.4 \pm 4.6$ \\
\hline \multicolumn{3}{|l|}{ Ethnicity - n (\%) } \\
\hline White & $2(22.2)$ & $3(37.5)$ \\
\hline Asian & $1(11.1)$ & $2(25.0)$ \\
\hline African American & $0(0.0)$ & $0(0.0)$ \\
\hline Hispanic & $6(66.7)$ & $2(25.0)$ \\
\hline American Indian/Alaska Native & $0(0.0)$ & $0(0.0)$ \\
\hline Hawaiian/Pacific Islander & $0(0.0)$ & $0(0.0)$ \\
\hline Other & $0(0.0)$ & $0(0.0)$ \\
\hline White/Hispanic & $0(0.0)$ & $1(12.5)$ \\
\hline Gender - n (\%) & $2(22.2)$ & $2(25.0)$ \\
\hline Male & $7(77.8)$ & $6(75.0)$ \\
\hline \multicolumn{3}{|l|}{ Female } \\
\hline Temperature & $98.3 \pm 0.4$ & $98.2 \pm 0.7$ \\
\hline Systolic blood pressure (SBP) & $113 \pm 11.9$ & $122 \pm 14.1$ \\
\hline Diastolic blood pressure (DBP) & $71.2 \pm 7.3$ & $73.4 \pm 9.2$ \\
\hline Pulse rate (bpm) & $70.4 \pm 7.6$ & $67.6 \pm 8.5$ \\
\hline Respiration rate & $15.6 \pm 1.9$ & $15.1 \pm 1.2$ \\
\hline Weight (kg) & $65.8 \pm 8.1$ & $66.2 \pm 7.7$ \\
\hline Height (cm) & $161.8 \pm 6.9$ & $162.1 \pm 8.6$ \\
\hline $\mathrm{BMI}\left(\mathrm{kg} / \mathrm{m}^{2}\right)$ & $24.8 \pm 3.2$ & $25.3 \pm 2.3$ \\
\hline
\end{tabular}

\section{Statistical Analysis}

The results were statistically analyzed using methods of descriptive and inferential statistics. The modified intent-to-treat analysis was conducted between the treatment groups. The pre/post differences were compared among the groups using an analysis of covariance model with the baseline value as the covariate. $P<0.05$ was determined as statistical significance 


\section{Results}

An original dataset composed of 55 participants [9] was filtered to included include only participants aged $\geq 50$ years. This filter yielded 17 total participants, 9 in the UC-II group and 8 in placebo. Both groups included 2 male participants while the UC-II group and placebo group were comprised of 7 and 6 females, respectively. Age, stature, and resting vitals were not statistically different between groups (Table 1).

After 120 days of supplementation, participants in the UC- $\|^{\circledR}$ group exhibited a statistically significant improvement versus placebo in KOOS items which include reduced pain during standing upright, going up or down stairs, decreased discomfort in climbing ascending stairs, bending to floor to pick an object, and squatting during period of high physical activity $(p<0.05$, Table 2$)$.

Table 2

KOOS individual physical functions score for placebo and UC-Iß囚 groups at baseline (Day 0) and final visit (Day 120).

\begin{tabular}{|c|c|c|c|c|c|}
\hline \multirow[b]{2}{*}{ KOOS Parameter } & \multicolumn{2}{|c|}{ Placebo $(n=8)$} & \multicolumn{3}{|c|}{ UC-IIß (n=9) } \\
\hline & BL & $\begin{array}{l}\text { Day } \\
120\end{array}$ & BL & $\begin{array}{l}\text { Day } \\
120\end{array}$ & $P$ value \\
\hline Going up or down stairs & $\begin{array}{l}3.375 \pm \\
0.52\end{array}$ & $\begin{array}{l}2.875 \pm \\
0.64\end{array}$ & $\begin{array}{l}3.222 \pm \\
1.09\end{array}$ & $\begin{array}{l}2.111 \pm \\
0.60\end{array}$ & $0.0289 *$ \\
\hline Standing upright & $\begin{array}{l}2.000 \pm \\
0.93\end{array}$ & $\begin{array}{l}2.000 \pm \\
0.93\end{array}$ & $\begin{array}{l}2.556 \pm \\
0.53\end{array}$ & $\begin{array}{l}1.556 \pm \\
0.53\end{array}$ & 0.0522 \\
\hline Ascending stairs & $\begin{array}{l}3.125 \pm \\
0.84\end{array}$ & $\begin{array}{l}3.125 \pm \\
0.99\end{array}$ & $\begin{array}{l}2.889 \pm \\
1.36\end{array}$ & $\begin{array}{l}2.000 \pm \\
0.87\end{array}$ & $0.0328 *$ \\
\hline Bending to floor/pick up an object & $\begin{array}{l}2.875 \pm \\
0.64\end{array}$ & $\begin{array}{l}3.125 \pm \\
0.99\end{array}$ & $\begin{array}{l}2.556 \pm \\
1.01\end{array}$ & $\begin{array}{l}2.222 \pm \\
0.44\end{array}$ & $0.0413^{*}$ \\
\hline Squatting & $\begin{array}{l}3.125 \pm \\
0.99\end{array}$ & $\begin{array}{l}3.125 \pm \\
0.84\end{array}$ & $\begin{array}{l}3.222 \pm \\
0.97\end{array}$ & $\begin{array}{l}2.111 \pm \\
0.78\end{array}$ & $0.0250 *$ \\
\hline $\begin{array}{l}\text { How much are you troubled with lack of } \\
\text { confidence in your knee? }\end{array}$ & $\begin{array}{l}3.375 \pm \\
0.92\end{array}$ & $\begin{array}{l}2.875 \pm \\
0.84\end{array}$ & $\begin{array}{l}2.333 \pm \\
0.5\end{array}$ & $\begin{array}{l}1.778 \pm \\
0.44\end{array}$ & $0.0196 *$ \\
\hline
\end{tabular}

\section{Discussion}

This study endeavored to investigate the effects of 120-days of undenatured type II collagen supplementation on KOOS survey scores in participants at least 50 years of age or above with exerciseinduced knee pain. The primary rationale for investigating this age group stems from prior knowledge that knee pain is known to increase with advancing age [15]. The findings support the study hypothesis as lower self-report pain, per the select KOOS survey items, was apparent in the undenatured type II collagen supplementation group over placebo at Day 120 of supplementation. 
Prior research indicated that undenatured type II collagen can increase anti-inflammatory cytokines (IL-4, TGF-beta) and decreases circulating levels of inflammatory cytokines (IL-2, IL-17) [18]. This combination can acutely lower the incidence of arthritic symptoms. The ability to modify the immune response after consumption of a food-based product, or an antigen, is called oral tolerance. Research into this mechanism of action has revealed that several distinct types of regulatory $T$ cells facilitate this occurrence by releasing anti-inflammatory cytokines. It has also been shown that this effect is transitory in nature, requiring that the food, or antigen, be consumed on a consistent basis to maintain the tolerogenic state [19]. Given these findings, it is plausible that supplementation with undenatured type II collagen might relieve joint discomfort and restore joint function in healthy participants via an acute immunomodulatory effect.

Exercise can cause pain and stiffness in knee joints which resembles the symptoms of localized inflammation [20]. Knee pain can present as a self-prescribed contraindication to exercise, many older adults living with knee pain possess uncertainty of their ability to exercise safely [6]. Moreover, mechanistic research suggests that intense or repetitive exercise leads to a decline in articular cartilage [21]. Thus, it may be that exercise can induce similar physiological outcomes to those that take place in arthritic disease [21]. While systematic reviews show that exercise is generally safe for adults with knee pain [22], individuals suffering from exercise-induced knee pain may remain wary of their ability to participate in a regimented exercise program. Reducing knee pain onset during exercise, then, is of great interest to this population as the benefits of exercise do not wane in old age [23].

In the United States, approximately 31 million osteoarthritic patients accumulated medical expenses exceeding 340 billion dollars between 2008 and 2011 [24]. Knee osteoarthritis is a prevalent health concern in the general population. In fact, the most frequent occurrence of symptomatic osteoarthritis is the knee joint, which affects nearly one quarter of the general population [25]. In individuals over 50 years old, osteoarthritis was reported to be the most common cause of knee pain [26]. Further, the onset of knee pain has been shown to decrease physical activity and potentially speed age-related muscle loss that is commonly referred to as sarcopenia [27]. Consequently, after the age of 50, individuals experience a steady decline in function that eventually leads to loss of independence [27]. Extensive data has demonstrated that knee pain presents with several psychological comorbidities including, but not limited to, depression, anxiety, and impairments in social interactions [28]. Furthermore, cross-sectional studies have reported a positive relationship between osteoarthritis and cardiovascular and metabolic diseases [29] while a systematic review indicated that the worsening of osteoarthritic pain paired with such diseases leads to greater deterioration in physical functioning [30]. Hence, remedies for osteoarthritic pain not only apply to localized pain, but to general health.

\section{Conclusions}

UC-II® is a unique nutritional supplement that has demonstrated support for joint health in humans [9] and animals $[10,11]$. In the current report, daily supplementation $(40 \mathrm{mg})$ of undenatured type II collagen for 120 days prompted significant improvements in KOOS survey scores compared to placebo in a cohort 
of participants aged at least 50 years who experienced exercise-induced knee pain. Indeed, participants in the undenatured type II collagen supplementation group exhibited significantly greater improvements in joint discomfort during standing upright $(39.12 \%$ vs $0 \%)$, ascending stairs $(30.8 \%$ vs $0 \%)$, going up or down stairs (34.5\% vs $14.8 \%$ ), bending to floor/picking up object $(13.1 \%$ vs $-8.7 \%$ ), and squatting (33.3\%2 vs $0 \%$ ). Thus, oral consumption of undenatured type II collagen could be an applied treatment to improve knee pain and function.

\section{Declarations}

Ethics approval and consent to participate

The original study was conducted in 2013 according to the guidelines of the Declaration of Helsinki, and approved by the Institutional Review Board (Copernicus Group IRB; Cary, NC). Current post hoc analysis data is from the original study 2013. Informed consent was obtained from all subjects involved in the study in 2013.

\section{Consent for publication}

All authors have read and agreed to the submitted version of the manuscript.

\section{Availability of data and materials}

The data presented in this study are available on request from the corresponding author.

\section{Competing interests}

Zainulabedin Saiyed, Shane Durkee, and Vijaya Juturu are employed by Lonza Consumer Health Inc. James Bowman is an independent statistical consultant who ran the analysis for the current manuscript on behalf of Lonza CHI Inc.

\section{Funding}

Lonza CHI Inc.

\section{Authors' contributions}

Conceptualization, ZS and VJ.; methodology and data collection, ZS, JB and VJ.; formal analysis, JB and VJ.; data curation, ZS., SD and VJ.; writing, review and editing - original draft preparation, supervision, project administration, ZS and VJ.

Acknowledgements

We thank Applied Science and Performance Institute (ASPI), Research Department, Tampa, FL for their support in writing and editing the manuscript. 


\section{References}

1. Bennell KL, Hinman RS. A Review of the Clinical Evidence for Exercise in Osteoarthritis of the Hip and Knee. J Sci Med Sport 2011; 14: 4-9, doi:10.1016/j.jsams.2010.08.002.

2. Blumenthal JA, Sherwood A, Gullette EC, Babyak M, Waugh R, Georgiades A, Craighead LW, Tweedy D, Feinglos M, Appelbaum M. et al. Exercise and Weight Loss Reduce Blood Pressure in Men and Women with Mild Hypertension: Effects on Cardiovascular, Metabolic, and Hemodynamic Functioning. Arch Intern Med 2000; 160: 1947-1958, doi:10.1001/archinte.160.13.1947.

3. Rynders CA, Weltman JY, Jiang B, Breton M, Patrie J, Barrett EJ, Weltman A. Effects of Exercise Intensity on Postprandial Improvement in Glucose Disposal and Insulin Sensitivity in Prediabetic Adults. J Clin Endocrinol Metab 2014; 99; 220-228, doi:10.1210/jc.2013-2687.

4. Slentz CA, Duscha BD, Johnson JL, Ketchum K, Aiken LB, Samsa GP, Houmard JA, Bales CW, Kraus WE. Effects of the Amount of Exercise on Body Weight, Body Composition, and Measures of Central Obesity: STRRIDE-a Randomized Controlled Study. Arch Intern Med 2004; 164: 31-39, doi:10.1001/archinte.164.1.31.

5. Barnes JN. Exercise, Cognitive Function, and Aging. Adv Physiol Educ 2015; 39: 55-62, doi:10.1152/advan.00101.2014.

6. Holden MA, Nicholls EE, Young J, Hay EM, Foster NE. Role of Exercise for Knee Pain: What Do Older Adults in the Community Think? Arthritis Care Res (Hoboken) 2012; 64: 1554-1564, doi:10.1002/acr.21700.

7. Kuru Çolak T, Kavlak B, Aydoğdu O, Şahin E, Acar G, Demirbüken İ, Sarı Z, Çolak İ, Bulut G, Polat MG. The Effects of Therapeutic Exercises on Pain, Muscle Strength, Functional Capacity, Balance and Hemodynamic Parameters in Knee Osteoarthritis Patients: A Randomized Controlled Study of Supervised versus Home Exercises. Rheumatol Int 2017; 37: 399-407, doi:10.1007/s00296-0163646-5.

8. D’Adamo S, Cetrullo S, Panichi V, Mariani E, Flamigni F, Borzì RM. Nutraceutical Activity in Osteoarthritis Biology: A Focus on the Nutrigenomic Role. Cells 2020; 9: 1232, doi:10.3390/cells9051232.

9. Lugo JP, Saiyed ZM, Lau FC, Molina JPL, Pakdaman MN, Shamie AN, Udani JK. Undenatured Type II Collagen (UC-II $\left.{ }^{\circledR}\right)$ for Joint Support: A Randomized, Double-Blind, Placebo-Controlled Study in Healthy Volunteers. J Int Soc Sports Nutr 2013; 10: 48, doi:10.1186/1550-2783-10-48.

10. Peal A, D’Altilio M, Simms C, Alvey M, Gupta RC, Goad JT, Canerdy TD, Bagchi M, Bagchi D. Therapeutic Efficacy and Safety of Undenatured Type-II Collagen (UC-II $\left.{ }^{\circledR}\right)$ Alone or in Combination with (-)-Hydroxycitric Acid and Chromemate in Arthritic Dogs. J Vet Pharmacol Ther 2007; 30: 275278, doi:10.1111/j.1365-2885.2007.00844.x.

11. Gupta RC, Bagchi D, Skaggs P, Stocker A, Wegford K, Goad JT, Canerdy TD, Bagchi M, Barnett D, Dewees W. Safety and Therapeutic Efficacy of Undenatured Type-li Collagen (UC-II ${ }^{\circledR}$ ) in Comparison 
to Glucosamine and Chondroitin in Arthritic Horses. J Anim Physiol and Anim Nutr 2009; 93: 142142, doi:https://doi.org/10.1111/j.1439-0396.2009.00921_3.x.

12. Bagchi D, Misner B, Bagchi M, Kothari SC, Downs BW, Fafard RD, Preuss HG. Effects of Orally Administered Undenatured Type II Collagen against Arthritic Inflammatory Diseases: A Mechanistic Exploration. Int J Clin Pharmacol Res 2002; 22: 101-110.

13. Gottardi R, Hansen U, Raiteri R, Loparic M, Düggelin M, Mathys, D.; Friederich, N.F.; Bruckner, P.; Stolz, M. Supramolecular Organization of Collagen Fibrils in Healthy and Osteoarthritic Human Knee and Hip Joint Cartilage. PLoS One 2016;11: e0163552, doi:10.1371/journal.pone.0163552.

14. He, Y.; Li, Z.; Alexander, P.G.; Ocasio-Nieves, B.D.; Yocum, L.; Lin, H.; Tuan, R.S. Pathogenesis of Osteoarthritis: Risk Factors, Regulatory Pathways in Chondrocytes, and Experimental Models. Biology (Basel) 2020; 9, doi:10.3390/biology9080194.

15. McAlindon TE, Cooper C, Kirwan JR, Dieppe PA. Knee Pain and Disability in the Community. Br J Rheumatol 1992; 31: 189-192, doi:10.1093/rheumatology/31.3.189.

16. Aletaha D, Neogi T, Silman AJ, Funovits J, Felson DT, Bingham CO, Birnbaum NS, Burmester GR, Bykerk VP, Cohen MD. et al. 2010 Rheumatoid Arthritis Classification Criteria: An American College of Rheumatology/European League Against Rheumatism Collaborative Initiative. Arthritis Rheum 2010; 62: 2569-2581, doi:10.1002/art.27584.

17. Roos EM, Roos HP, Ekdahl C, Lohmander LS. Knee Injury and Osteoarthritis Outcome Score (KOOS)-Validation of a Swedish Version. Scand J Med Sci Sports 1998; 8:439-448, doi:10.1111/j.16000838.1998.tb00465.x.

18. Tong T, Zhao W, Wu YQ, Chang Y, Wang QT, Zhang LL, Wei W. Chicken Type II Collagen Induced Immune Balance of Main Subtype of Helper T Cells in Mesenteric Lymph Node Lymphocytes in Rats with Collagen-Induced Arthritis. Inflamm. Res. 2010; 59: 369-377, doi:10.1007/s00011-009-0109-4.

19. Weiner HL, da Cunha AP, Quintana F, Wu H. Oral Tolerance. Immunol Rev 2011; 241: 241-259, doi:10.1111/j.1600-065X.2011.01017.x.

20. Shek PN, Shephard RJ. Physical Exercise as a Human Model of Limited Inflammatory Response. Can J Physiol Pharmacol 1998; 76: 589-597, doi:10.1139/cjpp-76-5-589.

21. Kiviranta I, Tammi M, Jurvelin J, Arokoski J, Säämänen AM, Helminen HJ. Articular Cartilage Thickness and Glycosaminoglycan Distribution in the Canine Knee Joint after Strenuous Running Exercise. Clin Orthop Relat Res 1992; 302-308.

22. Quicke JG, Foster NE, Thomas MJ, Holden MA. Is Long-Term Physical Activity Safe for Older Adults with Knee Pain?: A Systematic Review. Osteoarthritis and Cartilage 2015; 23: 1445-1456, doi:10.1016/j.joca.2015.05.002.

23. Giné-Garriga M, Roqué-Fíguls M, Coll-Planas L, Sitjà-Rabert M, Salvà A. Physical Exercise Interventions for Improving Performance-Based Measures of Physical Function in CommunityDwelling, Frail Older Adults: A Systematic Review and Meta-Analysis. Arch Phys Med Rehabil 2014; 95: 753-769.e3, doi:10.1016/j.apmr.2013.11.007. 
24. Yelin E, Weinstein S, King T. The Burden of Musculoskeletal Diseases in the United States. Semin Arthritis Rheum 2016;46: 259-260, doi:10.1016/j.semarthrit.2016.07.013.

25. Pereira D, Peleteiro B, Araújo J, Branco J, Santos RA, Ramos E. The Effect of Osteoarthritis Definition on Prevalence and Incidence Estimates: A Systematic Review. Osteoarthritis Cartilage 2011; 19 : 1270-1285, doi:10.1016/j.joca.2011.08.009.

26. Zeni JA; Axe MJ; Snyder-Mackler L. Clinical Predictors of Elective Total Joint Replacement in Persons with End-Stage Knee Osteoarthritis. BMC Musculoskelet Disord 2010;11: 86, doi:10.1186/1471-247411-86.

27. Torii M, Hashimoto M, Hanai A, Fujii T, Furu M, Ito H, Uozumi R, Hamaguchi M, Terao C, Yamamoto W. et al. Prevalence and Factors Associated with Sarcopenia in Patients with Rheumatoid Arthritis. Mod Rheumatol 2019; 29: 589-595, doi:10.1080/14397595.2018.1510565.

28. lijima H, Aoyama T, Fukutani N, Isho T, Yamamoto Y, Hiraoka M, Miyanobu K, Jinnouchi M, Kaneda E, Kuroki H. et al. Psychological Health Is Associated with Knee Pain and Physical Function in Patients with Knee Osteoarthritis: An Exploratory Cross-Sectional Study. BMC Psychol 2018; 6: 19, doi:10.1186/s40359-018-0234-3.

29. Yoshimura N, Muraki S, Oka H, Tanaka S, Kawaguchi H, Nakamura K, Akune T. Accumulation of Metabolic Risk Factors Such as Overweight, Hypertension, Dyslipidaemia, and Impaired Glucose Tolerance Raises the Risk of Occurrence and Progression of Knee Osteoarthritis: A 3-Year Follow-up of the ROAD Study. Osteoarthritis and Cartilage 2012; 20: 1217-1226, doi:10.1016/j.joca.2012.06.006.

30. Calders P, Van Ginckel A. Presence of Comorbidities and Prognosis of Clinical Symptoms in Knee and/or Hip Osteoarthritis: A Systematic Review and Meta-Analysis. Seminars in Arthritis and Rheumatism 2018; 47: 805-813, doi:10.1016/j.semarthrit.2017.10.016.

\section{Figures}




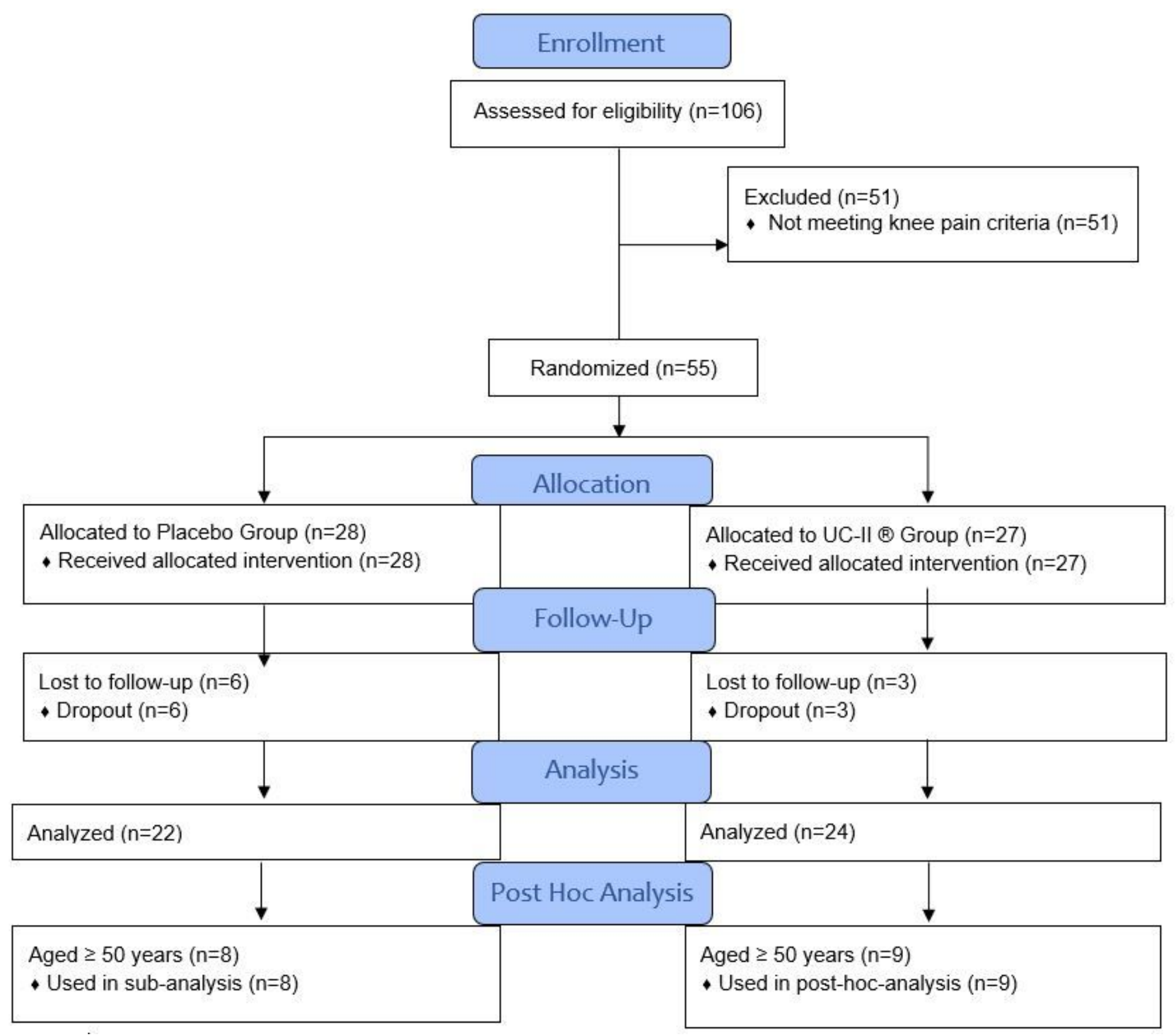

\section{Figure 1}

CONSORT Flow Diagram 